\title{
RADIOCARBON-DATED SUBFOSSIL STOMACH OIL DEPOSITS FROM PETREL NESTING SITES: NOVEL PALEOENVIRONMENTAL RECORDS FROM CONTINENTAL ANTARCTICA
}

\author{
ACHIM HILLER
}

Arbeitsgruppe Paläoklimatologie, Quartärzentrum der Universität Leipzig, Permoserstrasse 15
D-04303 Leipzig, Germany

WOLF-DIETER HERMICHEN and ULRICH WAND

Alfred-Wegener-Institut für Polar- und Meeresforschung, Forschungsstelle Potsdam
Postfach 600149, D-14473 Potsdam, Germany

\begin{abstract}
Radiocarbon dating is an important tool for reconstructing Late Quaternary paleoenvironmental history of the Antarctic continent. Because of the scarcity of datable material, new suitable substances are welcomed. We present here novel paleoenvironmental records-subfossil stomach oil deposits (mumiyo). This waxy organic material is found in petrel breeding colonies, especially in those of snow petrels, Pagodroma nivea. The substance is formed by accumulation and solidification of stomach oil regurgitated for the purpose of defense. We demonstrate and outline the usefulness and limitations of ${ }^{14} \mathrm{C}$ dating mumiyo for determining dates of local ice retreat, moraines and petrel occupation history.
\end{abstract}

\section{INTRODUCTION}

In the interior of Antarctica, radiocarbon dating for paleoenvironmental research is limited by the scarcity of organic deposits. Until now, ${ }^{14} \mathrm{C}$ measurements have been made mostly on (calcareous) shells from the coastal zone and, in a few cases, on faunal remains (e.g., bones and cadavers of seals, whales, penguins) and algal sediments (Stuiver and Braziunas 1985; Gordon and Harkness 1992). At several inland areas up to $>300 \mathrm{~km}$ from the coast, breeding colonies of snow petrels (Pagodroma nivea) and Antarctic petrels (Thalassoica antarctica) can be found. An exotic organic deposit can also be found at these sites, formed by the accumulation and solidification of petrel stomach oil, used for feeding offspring and often regurgitated for defense against rivals and enemies (Warham, Watts and Dainty 1976; Jacob 1982). The birds breed exclusively on snow- and ice-free sites in cavities and cracks on rocky hills, under or between large boulders (Fig. 1). The cold, arid climate prevents rapid microbial degradation of the organic substance and preserves it for a long time. Thus, around nesting sites, organic deposits may build up to $0.5 \mathrm{~m}$ thick.

The fresh stomach oil is orange, later transforming into a more-or-less distinctly stratified, wax-like material of yellowish-brown or gray color (Fig. 2). This is due to highly unsaturated oxidized lipids, yielding resinous products (Jacob 1982). To a varying degree, the deposits are mixed with rock fragments, fine-grained sediment, feathers and guano. The surface often shows polygonal cracks, presumably owing to the desiccation processes. The material has a high lipid content, thought to be due to krill (Euphausiidae), the major food source of petrels (Beck 1969; Kolattokudy 1976; Prince and Morgan 1987). Physical properties and chemical composition of Antarctic stomach oil deposits are similar to mumiyo (organic deposits of uncertain origin) found in the mountainous regions of Central Asia (Yusupov, Dzhenchuraev and Khatamov 1979), although Asian mumiyo has an entirely different genesis.

We discuss here the suitability for ${ }^{14} \mathrm{C}$ dating of stomach oil deposits of Antarctic snow petrels to decipher the Late Quaternary environmental history of (partly) deglaciated areas in the marginal zone of the ice-covered continent. 


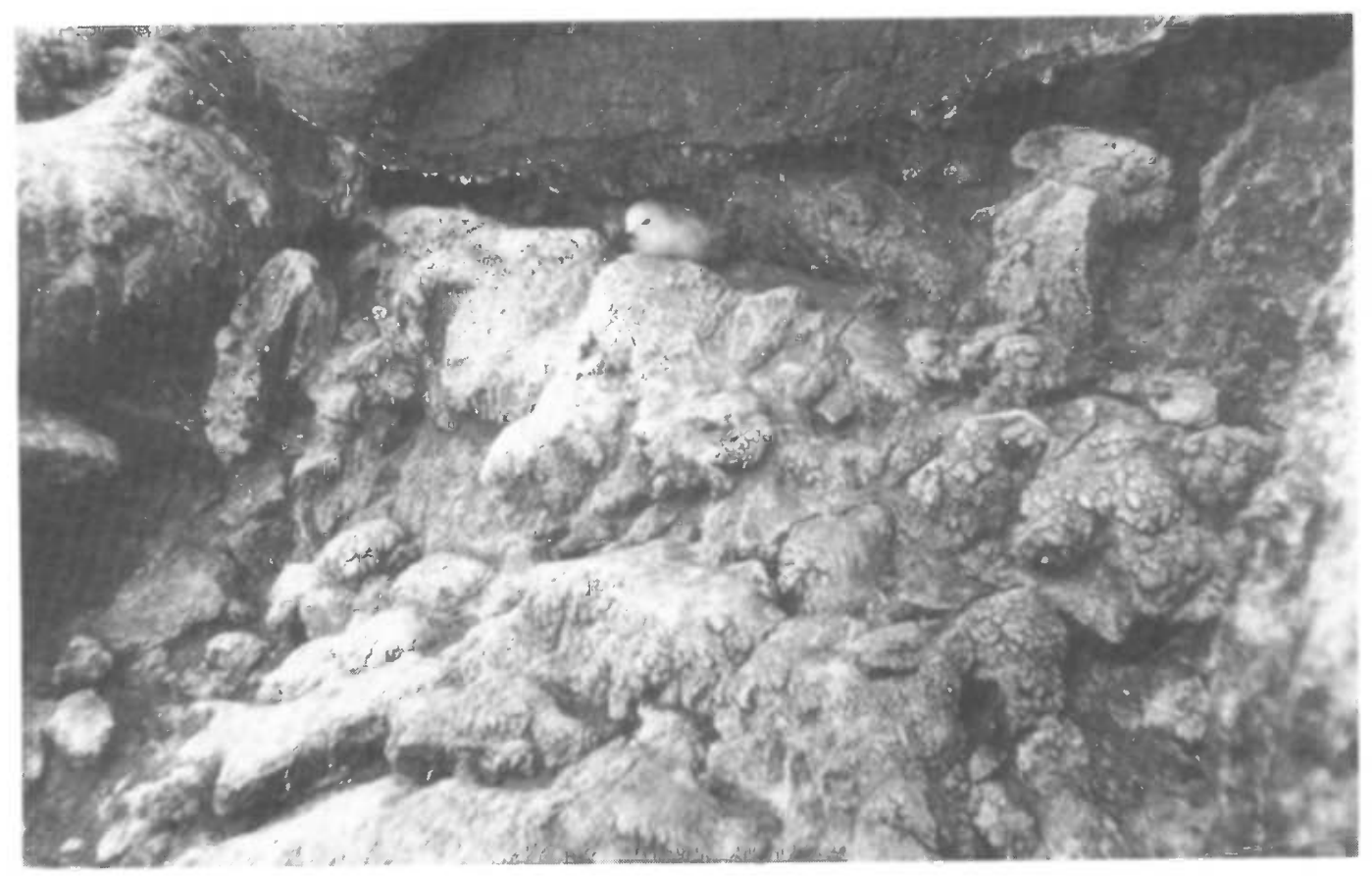

Fig. 1. Snow petrel at its breeding site. The boulders in the foreground are covered with stomach oil deposits.

\section{METHODS}

\section{Sampling}

Systematic ${ }^{14} \mathrm{C}$ studies on mumiyo have been conducted in Queen Maud Land in the Lake Untersee region $\left(71^{\circ} \mathrm{S}, 13^{\circ} \mathrm{E}\right)($ Hiller et al. 1988$)$, at the Insel Range $\left(72^{\circ} \mathrm{S}, 11^{\circ} \mathrm{E}\right)$, at the Robertskollen nunatak group $\left(71^{\circ} \mathrm{S}, 3^{\circ} \mathrm{W}\right)$ (Ryan et al. 1992$)$ and in the Bunger Hills $\left(66^{\circ} \mathrm{S}, 101^{\circ} \mathrm{E}\right)$ (Verkulich and Hiller 1994). Two samples were available from other Antarctic regions (Mount Provender $/ 80^{\circ} \mathrm{S}$, $30^{\circ} \mathrm{W}$; Radok Lake $/ 71^{\circ} \mathrm{S}, 68^{\circ} \mathrm{E}$ ) (Hiller et al. 1988). Figure 3 shows the sites of these studies.

The ice-free areas of the alpine-type mountains in central Queen Maud Land extend from $560 \mathrm{~m}$ above sea level (asl) (Lake Untersee basin) to $c a .3000 \mathrm{~m}$ asl (flanks of the highest peaks). The breeding places of petrels center on the northern parts of the ranges, where the elevation of the regional ice sheet surface is from 600 (Untersee area) to $1400 \mathrm{~m}$ asl. We found organic deposits up to some decimeters thick at altitudes to $c a .1000 \mathrm{~m}$ above the recent glacier surface, i.e., up to $1600 \mathrm{~m}$ asl in the Untersee region, and up to $1700 \mathrm{~m}$ asl in the Insel Range. The minimum distance to the ocean is 200 $\mathrm{km}$. We roughly estimate the number of petrels at $c a .1000$ individuals living in the surroundings of Lake Untersee and $c a .100$ individuals living at the Insel Range. Details of the local population dynamics and the general behavior of the birds in these areas are not yet known. Unlike the mountainous area of Queen Maud Land, the Bunger Hills are the largest ice-free area in the coastal zone of East Antarctica, with a maximum altitude of $165 \mathrm{~m}$ asl. The area is surrounded by glaciers. The minimum distance to the ocean is $70 \mathrm{~km}$. According to recent ornithological investigations (Bulavintsev, Golovkin and Denizova 1993), >2000 snow petrels breed there during the austral summer.

At the nesting sites, we collected samples using spades, crowbars and spatulas. Wherever possible, the thickest parts of a deposit were separated completely to obtain long and regularly stratified pro- 


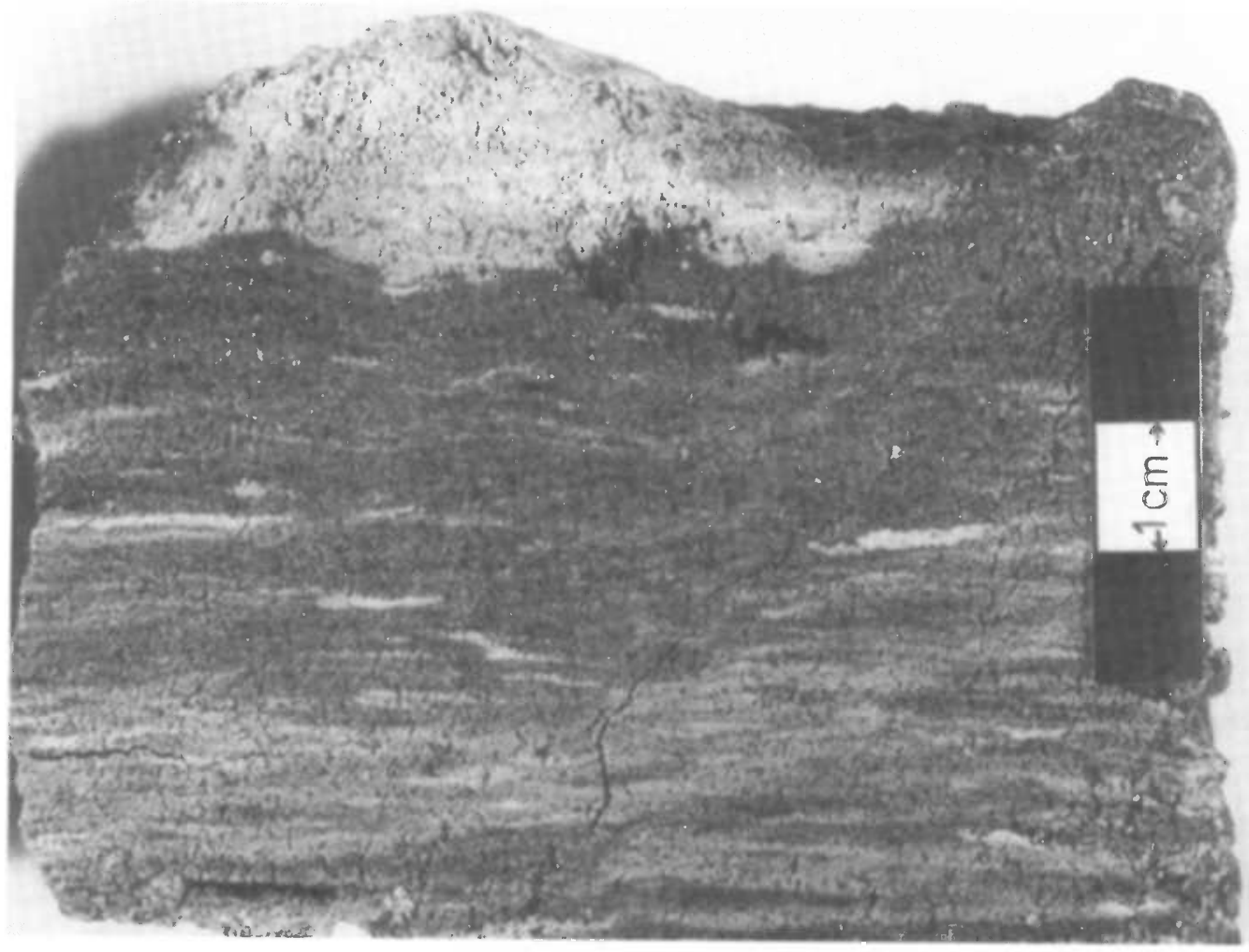

Fig. 2. Cross-section through a stratified stomach oil deposit

files. In some places, very large mumiyo deposits may occur, and samples frequently weighing several kilograms had to be collected. For the thin deposits, up to $10 \mathrm{~mm}$ thick, subsamples were cut only from the base and top. After sampling, the material was stored in plastic bags and kept frozen or cooled at $c a .5^{\circ} \mathrm{C}$ prior to analysis.

\section{Laboratory Procedures}

Subsamples were prepared by cutting slices, usually ca. 4-7 mm thick, parallel to the layering. Separating subsamples was difficult when no stratification was visible. All subsamples were treated with diluted hydrochloric acid to remove possible traces of carbonate and more mobile organic components. Samples of fresh stomach oil were used without pretreatment for further processing. The material was washed, carefully dried under an infrared lamp, stored over $\mathrm{P}_{2} \mathrm{O}_{5}$ in a desiccator for at least two days and converted to benzene in the usual manner. ${ }^{14} \mathrm{C}$ activities were measured in the Leipzig laboratory with Packard Tri-Carb ${ }^{\circledR 2} 260 \mathrm{XL}$ and $2560 \mathrm{TR} / \mathrm{XL}$ spectrometers. Some older dates were obtained with a Packard Tri-Carb ${ }^{\otimes 3} 375$ spectrometer. ${ }^{14} \mathrm{C}$ ages were calculated using the ${ }^{14} \mathrm{C}$ half-life of $5568 \mathrm{yr}$ and corrected for isotopic fractionation by normalizing the ${ }^{14} \mathrm{C}$ results to a $\delta^{13} \mathrm{C}$ value of $-25 \%$. 


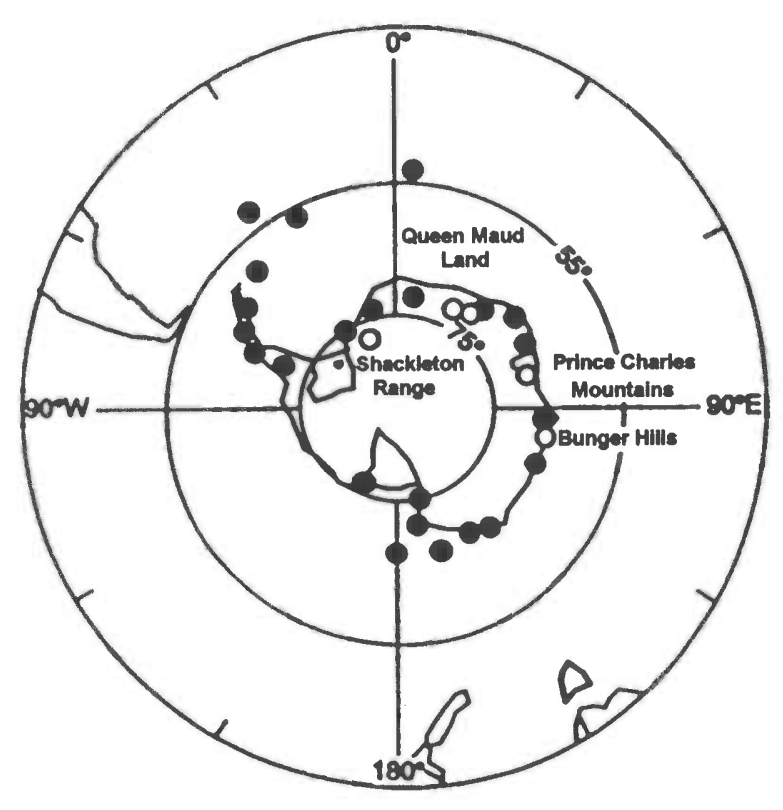

Fig. 3. Sketch map of known breeding colonies of snow petrels in the Antarctic (modified after Watson 1975). $O$ = studied petrel colonies; $\bullet=$ other petrel colonies.

\section{RESULTS AND DISCUSSION}

We dated 48 subsamples of subfossil stomach oil from 12 sites of the Lake Untersee region. The conventional ${ }^{14} \mathrm{C}$ dates cover a considerable age range; most are of Holocene age, but a few subsamples range beyond $c a .10 \mathrm{ka} \mathrm{BP}$ to $c a .35 \mathrm{ka} \mathrm{BP}$. A similar picture results from a collection of eight samples from the Insel Range. Further, $29{ }^{14} \mathrm{C}$ analyses were made from 16 mumiyo samples from Bunger Hills. Here, our attention focused on dates from basal subsamples, which have ${ }^{14} \mathrm{C}$ ages below $c a$. $10 \mathrm{ka} \mathrm{BP}$. Table 1 summarizes all the measurements. Seven modern samples of postnuclear origin (see below) were dated to estimate the magnitude of the regional reservoir effect (Table 2). We obtained a mean reservoir age of $800 \mathrm{BP}$. The first ${ }^{14} \mathrm{C}$ dates are also available from the Robertskollen area (Ryan et al. 1992), where a more extended series is under investigation. All measurements from this location, also reveal Holocene ages (Steele and Hiller, ms. in preparation). The $\delta^{13} \mathrm{C}$ values of subfossil stomach oil deposits range from ca. -27 to $-32 \%$; fresh stomach oil is somewhat more depleted, up to $c a$. $-33 \%$.

${ }^{14} \mathrm{C}$ dating of marine-derived material is influenced by the reservoir effect, which arises from the depletion of ${ }^{14} \mathrm{C}$ content in oceanic surface water compared with that of the atmosphere (Omoto 1983). Consequently, conventional ${ }^{14} \mathrm{C}$ ages of both recent and fossil marine biological samples are generally too old. The reservoir effect in different regions of the Southern Ocean not only varies over wide geographic areas (Stuiver and Braziunas 1985), but is also influenced by the uptake of bomb-produced ${ }^{14} \mathrm{C}$ (Michel and Linick 1985; Gordon and Harkness 1992). Hence, the reservoir age for recent samples of pre-nuclear time is somewhat higher than for those of post-nuclear time (Stuiver, Pearson and Braziunas 1986). Further, it is questionable whether the current reservoir age can be transferred to the past. Due to possible changes in the circulation pattern of oceanic water masses and the northward shift of the Antarctic Polar Front during glacial periods, the ${ }^{14} \mathrm{C}$ concentration in Antarctic surface waters could have decreased further by some hundreds of years beyond the Holocene (Gordon and Harkness 1992). Thus, the correction factor (cf. above) is estimated to be 
TABLE 1. Compilation and Age Span of Conventional and Reservoir-Age-Corrected ${ }^{14} \mathrm{C}$ Dates of Stomach Oil Samples from Different Breeding Sites in Antarctica

\begin{tabular}{|c|c|c|c|c|c|c|c|c|}
\hline \multirow[b]{2}{*}{ Sample } & \multirow{2}{*}{$\begin{array}{l}\text { Thick- } \\
\text { ness } \\
(\mathrm{mm})\end{array}$} & \multirow{2}{*}{$\begin{array}{c}\text { No. of } \\
\text { sub- } \\
\text { samples }\end{array}$} & \multicolumn{2}{|c|}{$\begin{array}{r}\text { Subsample } \\
\text { depth (mm) }\end{array}$} & \multicolumn{2}{|c|}{$\begin{array}{c}\text { Conventional }{ }^{14} \mathrm{C} \text { age } \\
(\text { yr BP } \pm 1 \sigma)\end{array}$} & \multicolumn{2}{|c|}{$\begin{array}{l}\text { Corrected age } \\
\text { (yr BP) }\end{array}$} \\
\hline & & & Top & Base & Top & Base & Top & Base \\
\hline \multicolumn{9}{|c|}{ Lake Untersee } \\
\hline W 1.1 & 100 & 7 & $0-5$ & $88-98$ & $4600 \pm 100$ & $8020 \pm 180$ & 3300 & 6720 \\
\hline W 1.2 & 80 & 2 & $0-7$ & $60-80$ & $4240 \pm 110$ & $6050 \pm 110$ & 2940 & 4750 \\
\hline W 2 & 28 & 4 & $0-5$ & $22-27$ & $3500 \pm 100$ & $4470 \pm 150$ & 2200 & 3170 \\
\hline W 3 & 25 & 2 & $0-5$ & $17-23$ & $1450 \pm 120$ & $2530 \pm 220$ & Recent & 1230 \\
\hline W 4 & 15 & 1 & & $8-15$ & & $2600 \pm 90$ & & 1300 \\
\hline W 6 & 100 & 6 & $0-5$ & $93-98$ & $3900 \pm 90$ & $5060 \pm 160$ & 2600 & 3760 \\
\hline W 9 & 65 & 3 & $0-5$ & $57-63$ & $2290 \pm 80$ & $3120 \pm 110$ & 990 & 1820 \\
\hline W 10 & 40 & 2 & $0-5$ & $32-38$ & $1500 \pm 70$ & $2880 \pm 90$ & 200 & 1580 \\
\hline W 42 & 100 & 7 & $0-4$ & $91-96$ & $11,250 \pm 250$ & $13,800 \pm 550$ & 9950 & 12,500 \\
\hline W 103 & 90 & 5 & $0-4$ & $83-88$ & $4560 \pm 90$ & $7830 \pm 160$ & 2360 & 6530 \\
\hline W 104 & 145 & 6 & \multicolumn{2}{|c|}{ Oldest: } & $5940 \pm 110$ & $\begin{array}{l}17,630 \pm 410 \\
18,360 \pm 370\end{array}$ & 4640 & $\begin{array}{l}16,330 \\
17,060\end{array}$ \\
\hline W 105 & 70 & 3 & $0-12$ & $60-70$ & $28,190 \pm 1800$ & $33,900 \pm 3000$ & 26,890 & 32,600 \\
\hline \multicolumn{9}{|c|}{ Insel Range } \\
\hline 8 & 35 & 2 & $0-5$ & $28-35$ & $10,860 \pm 170$ & $12,740 \pm 230$ & 9560 & 11,440 \\
\hline 0 & 35 & 2 & $0-4$ & $23-35$ & $2500 \pm 70$ & $3360 \pm 70$ & 1200 & 2060 \\
\hline I 2 & 38 & 1 & & $28-35$ & & $11,650 \pm 240$ & & 10,350 \\
\hline 3 & $55 ?$ & 2 & $0-5$ & $48-55$ & $2160 \pm 80$ & $2600 \pm 80$ & 860 & 1300 \\
\hline $5 \mathrm{~A}$ & 100 & 2 & $0-5$ & $95-100$ & $24,300 \pm 960$ & $28,400 \pm 1560$ & 23,000 & 27,100 \\
\hline 5B & & 1 & & $95-100$ & & $37,500 \pm 5800$ & \multirow{3}{*}{3750} & 36,200 \\
\hline 6 & 130 & 2 & \multirow{4}{*}{$0-5$} & $122-130$ & $5050 \pm 80$ & $11,100 \pm 180$ & & 9800 \\
\hline 4 & $90 ?$ & 1 & & $80-90 ?$ & & $1540 \pm 80$ & & 240 \\
\hline E-1 & 95 & 2 & & 88-95 & $4280 \pm 70$ & $8160 \pm 90$ & 2980 & 6860 \\
\hline E-3 & 55 & 1 & & $47-55$ & & $8720 \pm 90$ & & 7420 \\
\hline \multirow[t]{2}{*}{ E-4 } & 113 & 15 & $0-5$ & $106-112$ & $2800 \pm 70$ & $29,520 \pm 500$ & 1500 & 28,200 \\
\hline & & & \multicolumn{2}{|c|}{ Oldest: } & & $32,480 \pm 740$ & & 31,180 \\
\hline \multicolumn{9}{|c|}{ Bunger Hills* } \\
\hline $426^{\circ}$ & 100 & 4 & \multirow[t]{5}{*}{$5-15$} & $90-100$ & $2440 \pm 120$ & $10,070 \pm 80$ & \multirow[t]{5}{*}{1140} & 8770 \\
\hline 441 & 15 & 1 & & $10-15$ & & $1370 \pm 40$ & & recent \\
\hline 483 & 140 & 1 & & $130-140$ & & $6150 \pm 60$ & & 4850 \\
\hline В 21 & 135 & 1 & & $125-135$ & & $10,770 \pm 250$ & & 9470 \\
\hline 6001 & 140 & 1 & & $135-140$ & & $7370 \pm 100$ & & 6070 \\
\hline 6009 & 120 & 3 & \multirow[t]{5}{*}{$0-5$} & $110-120$ & $1150 \pm 70$ & $7300 \pm 120$ & \multirow[t]{5}{*}{ Recent } & 6000 \\
\hline 6018 & 80 & 1 & & $75-80$ & & $6700 \pm 100$ & & 5400 \\
\hline 6020 & 100 & 1 & & $95-100$ & & $9160 \pm 110$ & & 7860 \\
\hline 6048 & 35 & 1 & & $30-35$ & & $6480 \pm 90$ & & 5180 \\
\hline 6063 & 50 & 1 & & $45-50$ & & $1650 \pm 70$ & & 350 \\
\hline 6066 & 45 & 3 & \multirow[t]{2}{*}{$0-5$} & $40-45$ & $1310 \pm 70$ & $2170 \pm 80$ & \multirow[t]{2}{*}{ Recent } & 870 \\
\hline 6072 & 125 & 2 & & $120-125$ & & $7150 \pm 110$ & & 5850 \\
\hline 6077 & 95 & 4 & $0-5$ & $90-95$ & $4910 \pm 80$ & $7830 \pm 80$ & 3610 & 6530 \\
\hline 6084 & 100 & 1 & & $90-100$ & & $6660 \pm 70$ & & 5360 \\
\hline 6086 & 120 & 1 & & $110-120$ & & $9920 \pm 80$ & & 8620 \\
\hline 6087 & 100 & 3 & $5-15$ & $85-100$ & $3460 \pm 60$ & $10,140 \pm 80$ & 2160 & 8840 \\
\hline Mount 1 & nder, & leton $R$ & ange & & & & & \\
\hline MP 1 & 25 & 2 & $5-15$ & $20-25$ & $8970 \pm 250$ & $9770 \pm 200$ & 7670 & 8470 \\
\hline Radok & Princ & les $M t$ & & & & & & \\
\hline LR 1 & 40 & 3 & $0-4$ & $36-40$ & $1550 \pm 140$ & $2910 \pm 80$ & 250 & 1610 \\
\hline
\end{tabular}

*Sample series include individual samples dated at either the Leipzig (LZ) or St. Petersburg (LU) labs 
TABLE 2. Apparent ${ }^{14} \mathrm{C}$ Ages of Modern "Post-Bomb" Organic Samples from the Southern Ocean

\begin{tabular}{|c|c|c|c|c|}
\hline Sample & Origin & Lab no. & $\begin{array}{c}\delta^{13} C_{\text {PDB }} \\
(\% 0)\end{array}$ & $\begin{array}{l}{ }^{14} \mathrm{C} \text { age } \\
\text { (yr BP) }\end{array}$ \\
\hline Stomach oil/Daption capense & King George Island & LZ-216 & -31.8 & $700 \pm 60$ \\
\hline Stomach oil/Daption capense & King George Island & LZ-356 & -32.4 & $760 \pm 100$ \\
\hline $\begin{array}{l}\text { Penguin egg/Pygoscelis } \\
\text { adeliae (without shell) }\end{array}$ & Schirmacher Oasis & LZ-440 & -29.7 & $940 \pm 80$ \\
\hline Bird/Pagodroma nivea juv. & Lake Untersee & $\mathrm{Hv}-14231^{*}$ & -28.0 & $1070 \pm 55$ \\
\hline Stomach oil/Pagodroma nivea & Lake Untersee & LZ-568 & -32.4 & $550 \pm 80$ \\
\hline Stomach oil/Pagodroma nivea & Insel Range & LZ-768 & -32.1 & $720 \pm 70$ \\
\hline Stomach oil/Pagodroma nivea & $\begin{array}{l}\text { Cairn Peak; } \\
\text { Robertskollen }\end{array}$ & LZ-1068 & -33.3 & $800 \pm 70$ \\
\hline
\end{tabular}

${ }^{*} \mathrm{HV}=$ Hannover

ca. $1300 \mathrm{yr}$. This estimate is also consistent with the youngest ${ }^{14} \mathrm{C}$ ages of some top subsamples (cf. Table 1). All ${ }^{14} \mathrm{C}$ dates reported here are reservoir-age-corrected values.

The ${ }^{14} \mathrm{C}$ ages within almost all sequences investigated tend to increase with depth, i.e., mixing effects are of minor importance. This is not a matter of course, as a strictly linear relation between age and depth is not expected $a$ priori due to the primarily liquid nature of the accumulated substance, as well as the unevenness and slope of the breeding places (Fig. 1). Hence, problems with the proper separation of subsamples may occur.

Because petrels breed exclusively on ice-free sites, studies of mumiyo may provide information on ice-sheet dynamics. Provided that any site was occupied by petrels soon after the beginning of deglaciation, the minimum age of a deglaciated site or an old moraine, which reflects the former ice sheet volume, can best be estimated from the ${ }^{14} \mathrm{C}$ age of the basal layer of the organic deposit (Hiller et al. 1988). Disregarding mixing processes, the accumulation rate of a deposit can be roughly estimated. Varying accumulation rates presumably reflect the nesting frequency, governed by glacioclimatic factors, and could point to a discontinous use. However, the morphology of the ground surface in the vicinity of the nest will also affect the structure of a deposit.

In the Lake Untersee area, the conventional ${ }^{14} \mathrm{C}$ ages of the basal layers vary mainly between $c a .1$ and $7 \mathrm{ka}$ and confirm the expected Holocene occupation. Three samples (W-42, W-104, W-105) from presently unoccupied sites reveal surprisingly old ages for the basal layers: $12.5,17$ and 32.6 $\mathrm{ka}$. We obtained similar results from sites in the Insel Range, an area above $1400 \mathrm{~m}$ asl with considerably lower (by $c a .5^{\circ} \mathrm{C}$ ) local mean summer temperatures than in the Lake Untersee area. These findings suggest sufficiently good breeding conditions for petrels in central Queen Maud Land at the northern slopes of the mountains between 50 and $600 \mathrm{~m}$ above the modern ice sheet during the last $35 \mathrm{ka}$, even during the last glacial maximum, ca. $18 \mathrm{ka}$ ago. The predominant occurrence of basal ages $<12 \mathrm{ka}$ BP shows an increase of the petrel population after the beginning of post-Pleistocene warming. Because the colonization by petrels is also governed by the availability of feeding locations (Fraser and Ainley 1986), we suppose that during the Late Pleistocene, areas of open water (polynyas) for feeding (Cavalieri and Zwally 1986) must have existed near the Antarctic coast.

Calculated mean accumulation rates range from $c a$. 9 to $>100 \mathrm{~mm}$ per millennium, possibly indicating very different nesting frequencies (see above). But we also observe pronounced breaks in several profiles ( $c f$. Fig. 5). Besides W-105, which presumably shifted to a lower location, the rough correlation between ${ }^{14} \mathrm{C}$ ages and elevation (Hiller et al. 1988) demonstrates that petrels seem to have occupied gradually new, lower-elevation nesting sites following local ice retreat. The top lay- 
ers show only a few values of recent age. This may be due to reduced population breeding frequency during the last few thousand years, separation of subsamples that were too thick or, in some cases, inadequate sampling.

In Bunger Hills, the relation between ${ }^{14} \mathrm{C}$ dates of basal layers of deposits, their positions and thicknesses enables us to outline petrel occupation history following deglaciation (Verkulich and Hiller 1994). In accordance with Colhoun and Adamson (1992), our results suggest that the occupation began $c a .10 \mathrm{ka} \mathrm{BP}$, when a sufficiently large part of the oasis became ice-free. The present pattern of bird colonies developed during the last 5-7 ka. The absence of both stratigraphic breaks, age inversions in the deposits and any allochthonous samples suggest that there has not been a major glacial advance since $c a .7 \mathrm{ka}$ BP. Mean accumulation rates calculated for four profiles range from ca. $7-50 \mathrm{~mm}$ yr $10^{-3}$.

All $\delta^{13} \mathrm{C}$ values are significantly lower than usually observed for marine organisms (Williams and Linick 1975). This may be due to the high lipid content of stomach oil, as lipids are commonly known to be depleted in $\delta^{13} \mathrm{C}$ (e.g., Degens 1969). It is striking that samples dated to <ca. $14 \mathrm{ka}$ are generally depleted in $\delta^{13} \mathrm{C}$ compared with some older ones from the same site (Fig. 4). This tendency is more pronounced in the data from Lake Untersee. The question whether the changes of the $\delta^{13} \mathrm{C}$ values may reflect variations of carbon isotope composition in the ocean surface water or merely chemical degradation processes of particular constituents of the deposited material (e.g., unsaturated fatty acids) is still open. But our data could qualitatively confirm findings from planktonic foraminifera and phytoplanktonic organic material in ocean sediment cores (Sarnthein et al. 1988; Jasper and Hayes 1990) that the $\delta^{13} \mathrm{C}$ of marine organic carbon was ca. 2-3\%o greater during the last ice age.

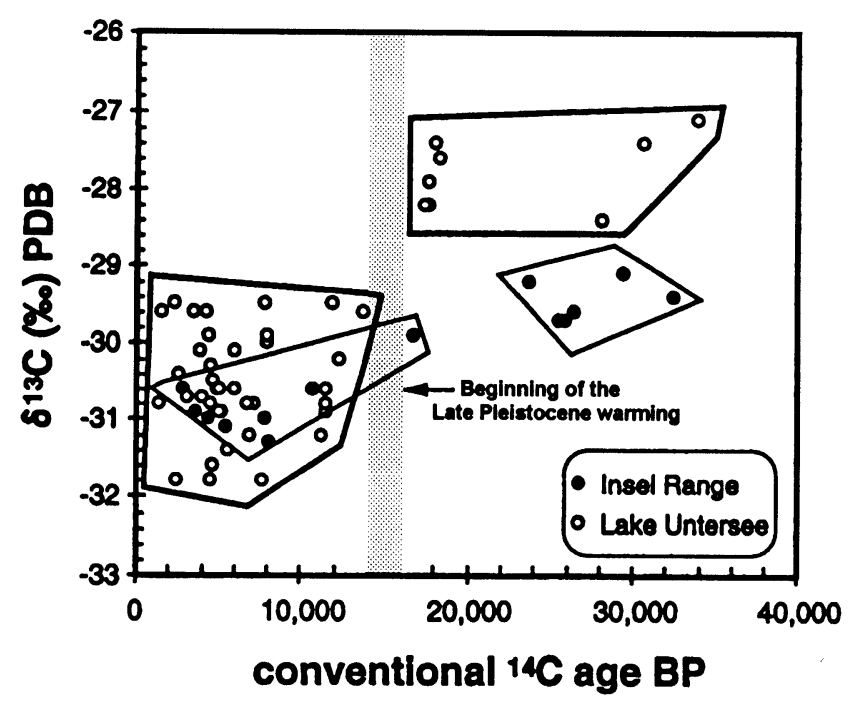

Fig. 4. Relation between $\delta^{13} \mathrm{C}$ values and conventional ${ }^{14} \mathrm{C}$ ages (not corrected for reservoir effect)

More paleoenvironmental information should be gathered either by investigating many basal layers or by detailed dating of several extended, well-stratified profiles in a petrel colony of a defined area. More evidence can thus be obtained on the breeding history of snow petrels, especially the time of their first occupation and the existence of any gaps in occupation. We made such an attempt by studying Sample E (Table 1) from a nesting site in Insel Range, $1470 \mathrm{~m}$ asl $(80 \mathrm{~m}$ above the recent local ice sheet margin contour line). The sample measured $50 \times 30 \mathrm{~cm}$, with a thickness of up to 14.5 $\mathrm{cm}$. Because preliminary dates of a few arbitrarily selected top and basal layers revealed quite dif- 
ferent ages, Sample E-4 was divided into 15 subsamples, the ${ }^{14} \mathrm{C}$ ages of which yielded an almost ideal picture (Fig. 5):

- a continuous sequence from 1.5-31.2 ka BP

- a uniform mean accumulation rate during the Holocene (ca. $\left.8 \mathrm{~mm} \mathrm{ka}^{-1}\right)$, markedly diminishing to $c a .1 \mathrm{~mm}$ per ka during the late glacial maximum

- only one minor age reversal at $\mathrm{ca}$. $30 \mathrm{ka} \mathrm{BP}$, possibly due to the penetration of some older material from the margin of this very large piece ( $c f$. above).

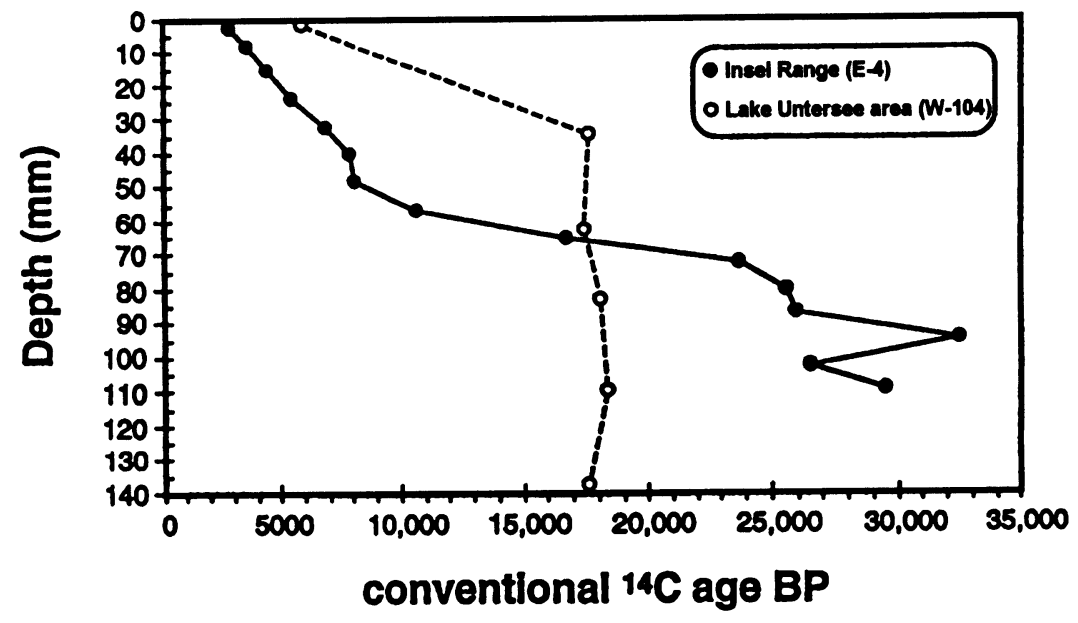

Fig. 5. Two examples of different ${ }^{14} \mathrm{C}$ depth profiles of stomach oil deposits (not corrected for reservoir effect). $\bullet=$ Profile E-4 (Insel Range; mean subsample depth, ca. $7 \mathrm{~mm}$ ); $\bigcirc$ = Profile W104 (Lake Untersee; mean subsample depth, ca. $8 \mathrm{~mm}$ ).

The interpretation of the oldest ${ }^{14} \mathrm{C}$ age of the basal layer as a minimum age of the ice-free area, however, may be subject to qualification. It seems possible that some sites became ice-free long before petrel settlement. Comparison with ${ }^{14} \mathrm{C}$ measurements on organic lake sediment columns from Queen Maud Land and Bunger Hills could prove valuable, and are presently under investigation. Initial ${ }^{14} \mathrm{C}$ dates on organic lake sediments from Bunger Hills (Bolshiyanov et al. 1991; Verkulich and Melles 1992; Melles, Verkulich and Hermichen 1994) fit well with our mumiyo results. Deciphering the Late Quaternary environmental history of the marginal zone of the Antarctic continent requires multidisciplinary investigation from the continent as well as from its marine surroundings.

\section{CONCLUSION}

${ }^{14} \mathrm{C}$ dating stomach oil deposits of Antarctic snow petrels has led to the following conclusions:

1. Subfossil stomach oil deposits from snow petrels represent a new and interesting material for ${ }^{14} \mathrm{C}$ dating the paleoenvironmental history of numerous locations in the interior of Antarctica.

2. In distinctly stratified deposits, ${ }^{14} \mathrm{C}$ ages tend to increase with depth, i.e., mixing effects and/or post-depositional disturbances are of minor importance.

3. Because petrels breed exclusively on ice-free sites, information can be obtained about the timing of the local ice retreat. Minimum ages of moraines and exposure periods for nunataks can also be estimated from the oldest ${ }^{14} \mathrm{C}$ dates of basal layers. 
4. Our results confirm the expected Holocene occupation of the areas studied. Some ${ }^{14} \mathrm{C}$ ages up to $c a .35 \mathrm{ka}$ BP at places in central Queen Maud Land suggest, however, that breeding colonies of petrels must have existed long before the Late Pleistocene global warming and also during the last glacial maximum.

5. Both the investigation of a great number of basal layers and the detailed dating of several extended, well-stratified profiles are required for more paleoenvironmental information.

\section{ACKNOWLEDGMENTS}

We wish to thank Dr. W. Kurze for providing stomach oil sample E from the Insel Range. We are grateful to $\mathrm{H}$. Seipold for her help in preparing the manuscript for publication. This is contribution no. 859 of the Alfred Wegener Institute for Polar and Marine Research.

\section{REFERENCES}

Beck, J. R. 1969 Food, moult and age of first breeding in the Cape pigeon, Daption capensis Linnaeus. British Antarctic Survey Bulletin 21: 33-44.

Bolshiyanov, D., Verkulich, S., Klokov, V., Makeev, V. and Arslanov, H. 1989 Radiocarbon dating of sediments from the Bunger Oasis (East Antarctica). In Wand, U. and Strauch, G., eds. Proceedings of 5th Working Meeting, Isotopes in Nature. Leipzig, Central Institute of Isotope and Radiation Research: 47-52.

Bolshiyanov, D., Verkulich, S., Pushina, Z. and Kirienko, E. 1991 Some features of the Late Pleistocene and Holocene history of the Bunger Hills (East Antarctica). In 6th International Symposium on Antarctic Earth Sciences, (Abstracts). Tokyo, National Institute of Polar Research: 66-71.

Bulavintsev, V. I., Golovkin, A. N. and Denisova, A. V. 1993 Snow petrel as a prospective subject of combined ecological monitoring in the Antarctic. Antarktika. Doklady komissii 31: 167-178 (in Russian).

Cavalieri, D. J. and Zwally, H. J. 1986 Satellite observations of sea ice. Advanced Space Research 5: 247255.

Colhoun, E. A. and Adamson, D. A. 1992 Raised beaches of the Bunger Hills, Antarctica. ANARE Reports, No. 136: 47 p.

Degens, E. T. 1969 Biogeochemistry of stable carbon isotopes. In Eglinton, G. and Murphy, M. T. J., eds., Organic Geochemistry. Berlin, Springer-Verlag: 304 329.

Fraser, W. R. and Ainley, D. G. 1986 Ice edges and seabird occurrence in Antarctica. Bioscience 36: 258263.

Gordon, J. E. and Harkness, D. D. 1992 Magnitude and geographic variations of the radiocarbon content in antarctic marine life: Implications for reservoir corrections in radiocarbon dating. Quaternary Science Reviews 11: 697-708.

Hiller, A., Wand, U., Kämpf, H. and Stackebrandt, W. 1988 Occupation of the Antarctic continent by petrels during the past 35000 years: Inferences from a ${ }^{14} \mathrm{C}$ study of stomach oil deposits. Polar Biology 9: 69-77. Jacob, J. 1982 Stomach oils. In Farner, D. S., King, J. R. and Parkers, K. C., eds., Avian Biology, Vol. 6. New York, Academic Press: 325-340.

Jasper, J. P. and Hayes, J. M. 1990 A carbon isotope record of $\mathrm{CO}_{2}$ levels during the late Quaternary. $\mathrm{Na}$ ture 347: 462-464.

Kollatokudy, P. E., ed, 1976 Chemistry and Biogeochemistry of Natural Waxes. Amsterdam, Elsevier: 460 p.

Melles, M., Verkulich, S. R. and Hermichen, W. D. 1994 Radiocarbon dating of lacustrine and marine sediments from the Bunger Hills, East Antarctica. Antarctic Science 6(3): 375-378.

Michel, R. L. and Linick, T. W. 1985 Uptake of bombproduced carbon-14 by the Weddell Sea. Meteoritics 20: $423-435$.

Omoto, K. 1983 The problem and significance of radiocarbon geochronology in Antarctica. In Oliver, R. L., James, P. R. and Jago, J. B., eds., Antarctic Earth Science. Canberra, Australian Academy of Science: 450-452.

Prince, P. A. and Morgan, R. A. 1987 Diet and feeding ecology of Procellariiformes. In Croxall, J. P., ed., Seabirds: Feeding Ecology and Role in Marine Ecosystems. Cambridge, Cambridge University Press: 135-171.

Ryan, P. G., Steele, W. K., Siegfried, W. R. and Vogel, J. C. 1992 Radiocarbon dates of snow petrel regurgitations can reveal exposure periods for nunataks in Antarctica. South African Journal of Science 88: 578580.

Sarnthein, M., Winn, K., Duplessy, J.-C. and Fontugne, M. R. 1988 Global variations of surface ocean productivity in low and mid latitudes: Influence of $\mathrm{CO}_{2}$ reservoirs of the deep ocean and atmosphere during the last 21,000 years. Paleoceanography 3: 361399.

Stuiver, M. and Braziunas, T.F. 1985 Compilation of isotopic dates from Antarctica. Radiocarbon 27(2A): 117304. 
Stuiver, M., Pearson, G. W. and Braziunas, T. 1986 Radiocarbon age calibration of marine samples back to 9000 cal yr BP. In Stuiver, M. and Kra, R. S., eds., Proceedings of the 12 th International ${ }^{14} \mathrm{C}$ Conference. $\mathrm{Ra}$ diocarbon 28(2B): 980-1021.

Verkulich, S. R. and Hiller, A. 1994 Holocene deglaciation of the Bunger Hills revealed by ${ }^{14} \mathrm{C}$ measurements on stomach oil deposits in snow petrel colonies. Antarctic Science 6(3): 395-399.

Verkulich, S. R. and Melles, M. 1992 Composition and paleoenvironmental implications of sediments in a freshwater lake and in marine basins of Bunger Hills, East Antactica. Polarforschung 60: 169-180.

Warham, J., Watts, R. and Dainty, R. J. 1976 The compo- sition, energy content and function of the stomach oils of petrels (Order Procellariiformes). Journal of Experimental Marine Biology and Ecology 23: 1-13.

Watson, G. E. 1975 Birds of the Antarctic and Subantarctic. American Geophysical Union, Antarctic Research Series 24: $350 \mathrm{p}$.

Williams, P. M. and Linick, T. W. 1975 Use of naturally occurring radiocarbon as a long and short term tracer. In Isotope Ratios as Pollutant Source and Behaviour Indicators. Vienna, IAEA: 153-167.

Yusupov, R. G., Dzhenchuraev, D. D. and Khatamov, S. 1979 Geochemical peculiarities of Central Asian mumiyo. Geokhimiya 10: 1534-1540 (in Russian). 